\title{
Brief Discussion on the Generation, Current Situation and Prospect of Chinese Korean Ethnic Folksong
}

\author{
Yongchun Piao \\ College of Arts Yanbian University, Yanji Jilin, 133002, China
}

Keywords: Chinese Korean ethnic folksong, Generation, Current situation, Prospect.

\begin{abstract}
Chinese Korean ethnic folksong created during the war years is an important component of Chinese Anti-Japanese War song system, and plays a significant role in stimulating ethnic Korean people's anti-Japanese enthusiasm and inspiring the morale of the army. It is worthy of in-depth exploration. This article has retrospected the generation course of Chinese Korean ethnic folksongs, analyzed the development status of Chinese Korean folksongs, and elaborated the future prospect of Chinese Korean ethnic folksongs.
\end{abstract}

\section{Introduction}

Chinese Korean ethnic folksong has distinct characteristics of smooth and natural melody, lively rhythm, and rich rhythmicity. Some tunes also have the style of dance music, which is a feature of Korean music well known by people. Among a large number of Chinese Korean music, folksongs can be considered as the essence, as well as one of the very important parts of our national minority music system. In view of this, strengthening study of the generation, current situation and prospects of Chinese Korean folksongs will help further promote the development of China's Korean folk art.

\section{Review of the generation course of Chinese Korean ethnic folksongs}

Folksongs in the scope of Chinese art can reflect the unique cultural characteristics of a nation. There is no doubt that the generation of ethnic culture cannot be separated from the tremendous influence of history, society and politics. In the modern history of China, the Korean ethnic people in China have experienced a very miserable course. Under the influence of Chinese politics, economy, and traditional culture, the Korean nationality have the same cultural characteristics as other ethnic minorities in China, and also have cultural differences which develop and integrate with traditional culture in a specific environment and its, and then form folksong works with its own unique style. Therefore, culture which never emerged and exist in isolation is the product of comprehensive development.

\subsection{Traditional folksong of Korean Peninsula traditional folksongs are the origin of Chinese Korean ethnic folksongs.}

Korean Peninsula traditional folksongs include labor ballad, lyric ballad, custom ballad, and nursery rhymes. The genres of above folksongs show a variety of features and rich content, which provide a large number of valuable information for studying Chinese Korean ethnic folksongs. Labor ballad and lyric ballad are the important foundations for the generation of Chinese Korean ethnic folksong melody. With compliment of ordinary workers and good life as important themes, labor ballad and lyric ballad have laid very important foundation for the development of other types of folksongs. Labor ballad is usually used for casual singing in production labor work. For example, when planting rice, peasants need to show group harmony and the relatively fast-paced rhythm of agricultural activities. In this way, a large number of labor songs were produced in various civil engineering projects. The lyrical songs which can express distinctive features of joy, anger, grief, are important ways for Chinese Korean ethnic people to express their own inner feelings. Most folksongs 
praise nature, praise new life, and express love related content with smooth and bright tone and melody, changeable rhythm, not limited to one type. It has created unlimited space for the development of folksongs.

\subsection{The trend of new culture and the development of education are catalysts for the generation of Chinese Korean ethnic folksongs.}

From the Sino-Japanese War to the beginning of the 20th century, Western imperialist powers began frantically plundering colonies and conducted missionary activities in China, the DPRK, and Japan. As Catholicism and Christianity were introduced to North Korea, with the transmission and popularity of chorale, Chinese Korean ethnic folksongs were produced. The establishment of Korean schools in northeastern China also provided good places for the external transmission of chorale. Meanwhile, Changga class that symbolized the development trend of the era, namely, music lesson was produced. Changga is the transliteration of singing in Chinese. At this time, Changga began to gradually approach modern and contemporary songs in Western countries. After Japan swallowed up North Korea in 1910, the contents of the Changga were transformed into eager for the liberation and independence of the motherland. It has spread among Chinese Korean minorities and Korean peninsulas for more than 50 years in form of popular songs. We can say that the Changga is an inevitable outcome of the introduction of modern ideological trend in western countries and the Korean ethnic people's national independence movement. It plays a transitional role in the development of Chinese Korean ethnic songs from classical to new forms. The music classes run by Korean ethnic schools in China have accelerated the dissemination of western music culture, and also played a good role in the spread and popularity of Changga. After the founding of New China, orchestra was set up in China's Korean ethnic schools, which originated from the previous foundation. The continuous development of culture and education has promoted the continuous improvement of Chinese Korean ethnic people's overall cultural level, which has laid solid foundation for the generation of Chinese Korean ethnic folksongs in the future.

\subsection{Cultural literacy and national temperament are important foundation for the generation of Chinese Korean ethnic folksongs.}

The development of Korean ethnic education in the past and the fine tradition of paying attention to the children's education have played a very good role in improving Korean ethnic people's cultural literacy and national quality. Good education and cultural qualities have promoted Chinese Korean ethnic people to quickly receive new things, and improved their adaptability to the living environment. University for nationalities have been built in the Yanbian area where Chinese Korean ethnic people are inhabited early in the founding of the People's Republic of China. And thereafter primary and secondary education was popularized. By early in 1990s, the number of undergraduates per thousand Koreans in China reached 43, doubled the average rate of college students in the country during the same period. As a result, Korean minority in our country has the highest education popularizing rate and highest education level among all nationalities. Education has promoted the development of culture, and the further prosperity of culture has promoted the implementation of artistic activities including folksongs, so that Korean ethnic folksong art has become the most direct and original way of expressing individual emotions and reflecting the group will, thus in turn promoting Korean ethnic people's thinking mode to advance in practical direction.

\section{Analysis of the development status of Chinese Korean ethnic folksongs}

To adapt to economic development needs of Korean minority, and to protect their own culture, especially the music culture, since 1950s, due to the great attention and support from the party and government, folk music artists' unremitting efforts, China's Korean ethnic music has experienced full development and reform. In May 1954, China published the first "Collection of Folk Songs", which included more than fifty classic folk songs of various nationalities. After the end of the Cultural Revolution, China began the reform and opening up. In order to better preserve Korean ethnic folk art 
in our country, the government made a decision to vigorously implement the compilation of Korean ethnic folk music books. The publishers in Liaoning and Heilongjiang provinces were committed to issuing similar books in Korean. In the following period of time, works such as "The Folk Songs of the Korean Ethnic Group", "Selection of Yanbian Folk Songs", "Collection of Folk Songs of Korean Nationalities", and "Integration of Chinese Folk Songs/Liaoning Volume/Jilin Volume/Heilongjiang Volume" were successively published, thereby promoting the arrangement of folk art theory of Korean ethnic folk songs. A considerable part of the Korean ethnic folksongs were produced in the revolutionary war years, and then experienced a decade of cultural calamity. Thus, a large number of excellent folksongs were banned from being published as a negative teaching material propagating feudal dross thoughts. So the number of few reserved Korean ethnic folksongs is decreasing. Therefore, it is necessary to systematically summarize and research Chinese Korean ethnic folksongs.

\section{Future prospect of Chinese Korean ethnic folksongs}

\subsection{Carry out school site integration and construction of ethnic music research center in Korean minority agglomeration}

After entering the era of knowledge-driven economy, university as important base for talents training, knowledge dissemination and transformation is connecting with regional society closely. The music major in China's colleges and universities responsible for cultivating more high-quality music talents for local economic construction and social development is of great importance in building a harmonious society and promoting the prosperity of culture. It is necessary to actively create a national music center based on the characteristics of local colleges and universities as important entry points and resources. In accordance with the characteristics of local economic and social development and local demand for talents, relevant work should be carried out according to the actual conditions of the local community to focus on the local area, target at the local communities and serve local economy. Cultivation of utility-type talents suitable for local economic and social development can promote the development of China's national music resources. To reflect nationality and regionality, it is also necessary to strengthen cooperation with universities and select outstanding ethnic students for key training in order to promote the external communication and inheritance of local Korean ethnic folk art. Therefore, it is necessary to introduce reasonable plans for cultivating high-quality Korean talents, carry out specific curriculum construction in accordance with the requirements for personnel training, and strive to establish practical training bases, continuously improve utilization efficiency, and comprehensively improve the in-post training, social services and vocal art practice and other related procedures of ethnic talent training. Meanwhile, it is also necessary to actively investigate the specific needs of ethnic music talents in the area and conduct a comprehensive study on the protective development of local Korean ethnic music. Focusing on cooperation between school sites, it is expected to achieve the goal of nurturing high-level talents and serving regional society.

\subsection{Spare efforts to cultivate intangible cultural heritage inheritors of Chinese Korean ethnic folksongs}

Chinese Korean ethnic folksong is in the category of intangible cultural heritage, which requires to cultivate non-genetic inheritors. Inheritors should focus on cultivating Korean ethic singers, supplemented with Han singers because the Korean ethic music people have inherent sensitivity to their own music culture and can use their remarkable ethnic advantages to inherit their excellent music culture. When Han musicians learn Korean ethic folksongs with Korean musicians, they can better develop Korean ethic folk songs in the process of exchanges and discussions with each other. Meanwhile, it is also possible to increase their own knowledge by learning from the long-standing folksongs of the Korean ethic folk entertainment artists, and to add their own newest understanding of national music, to promote more musicians to become non-genetic inheritors and communicators.

\subsection{Establish the platform for external display of Chinese Korean ethnic folksongs}


Korean ethic music in the new situation should be meet the new spiritual needs of modern people based on the characteristics of the new era in new forms. In this way, we can have more audience bases, and thus radiate new vitality. Therefore, relevant departments should organize Korean ethic folk artists to actively carry out various types of singing contests or theatrical performances. It is necessary to continuously, profoundly excavate and sort out the traditional Korean ethnic folksongs to establish ethnic folk art stage to actively invite the Korean ethnic music masters to compete and demonstrate their skills in an all-round way. It is necessary to use effective methods such as going out and introducing in, encouraging all interested musicians to learn from Korean ethnic folksong artists in an open-minded manner, and to actively collect and sort out the scattered Chinese Korean ethnic folksongs so that it can become an important link to strengthen the emotional communication between ethnic groups.

\subsection{Promote mutual exchange of music culture between nationalities}

Music and cultural exchange between ethnic groups played a very important role in history, which is also one of the important means for the sustainable development of various ethnic music cultures in communication. The traditional Korean ethnic folksongs were influenced by various factors during its development, especially influenced by the ancient Chinese culture and arts, and then formed a traditional Korean ethnic folk art form which can manifest its own characteristics. A large number of Korean ethnic folk songs spread in the areas where Korean minorities live. Although most of them primarily reflected labor, life and other aspects, with the passage of time, various types of regenerated art forms were inherited and spread among people. A vast majority of them are ethnic art forms left by the ancestors, and they are also regenerative music art forms with local artistic characteristics. The author believes that in the process of cultural and musical exchanges with other nations, Chinese Korean ethnic folksongs which will not be heterogenous will adapt to the current new social and natural environment and thus display greater charm.

\section{Conclusion}

In conclusion, as a precious cultural resource that cannot be regenerated, it is of significant value to protect and inherit the famous Chinese Korean ethnic folksongs from the perspective of protecting the diversity of the Chinese nation's music culture and the balance of cultural ecology, or from the perspective of retaining the memory of the Chinese nation and inheriting the spirit of the national spirit. As an important music art form, it can display the inherent artistic spirit and aesthetic characteristics. Therefore, we must strive to maintain its exuberant vitality, so that the Chinese Korean ethnic folksongs, the Chinese national art treasures, can be inherited forever so as to make greater contributions to the development of our national music culture.

\section{Acknowledgement}

This research was financially supported by the Yanbian University school-level project, Subject name: Studies of long and short rhythm in Chinese Korean ethnic folksong. No.: QN2016008.

\section{References}

[1] Nan Xizhe. Chinese Korean ethnic music culture, Beijing: Nationality Publishing House, 2005. [2] Ju Shanri. Exploration of Chinese Korean ethnic folksong artistic characteristics, Inner Mongolia Art, 2007(2).

[3] Wang Beibei. Analysis on the educational function of Chinese Korean ethnic folksongs, Technology Wind, 2011(22).

[4] Li Hongmei. Artistic characteristics and culture connotation of Chinese Korean ethnic folksongs-Take the folksong “Arirang” as the example, Art Studies, 2013(3). 